\title{
TESTING THE RELATIONSHIP AMONG MACROECONOMIC VARIABLES AND FOREIGN DIRECT INVESTMENT INFLOWS IN PAKISTAN
}

\author{
Muhammad Usman \\ School of Accounting and Finance, Faculty of Management Studies \\ University of Central Punjab, \\ Lahore Pakistan \\ malikgee86@yahoo.com \\ Muhammad Ahmad \\ School of Accounting and Finance, Faculty of Management Studies \\ University of Central Punjab, \\ Lahore Pakistan \\ muhammadahmad@ucp.edu.pk
}

DOI: $10.31364 / \mathrm{SCIRJ} / \mathrm{v} 6.18 .2018 . P 0818546$

http://dx.doi.org/10.31364/SCIRJ/v6.i8.2018.P0818546

\begin{abstract}
Foreign direct investment is considered to be an important factor in economic growth of a country and in most of the developing countries such as Pakistan, FDI inflows is seen as vital catalyst for its development. It improves the economic growth of a country by simulating native investment, facilitating technology transfers in recipient country and increasing human capital development. This study is analyzed to check the impact and relationship of selective macroeconomic variables such as terrorism, inflation rate, market size, interest rate, democracy, and trade openness on foreign direct investment in Pakistan for the period of 1980 to 2013 through ARDL approach. The major findings of this study show that inflation rate, interest rates, democratic GOVT regimes and terrorism attacks are affecting the FDI inflows in Pakistan and all has long run association with FDI, whereas in short run inflation, interest rates and terrorism attacks show negative and market size show positive relationship with FDI inflows in Pakistan. Furthermore, trade openness has no impact on FDI in both long run and short run and is insignificant. The findings of this study suggest that increased interest rates and inflation rates in Pakistan will cause lower FDI inflows. The gross domestic product as market size increases it has positive impact on FDI inflows in Pakistan. The terrorisms attacks are major problem for Pakistan's economy. The results show that previous terrorism attacks are affecting FDI inflows negatively in the short time span, but in long run it becomes positive. It means Pakistan economy has capacity to cover its problems and not much suffers from such attacks.
\end{abstract}

Keywords: Macroeconomic variables and FDI inflows, FDI inflows in Pakistan, ARDL approach, Pakistan

\section{INTRODUCTION}

The economic growth of Pakistan is not satisfactory during past couple of years. There are many factors which are liable for this insufficient growth that are, mounting growth rates of imports, thin array of exports, imperfect banking system with increase interest rates, political insecurity, increasing population growth and high inflation rates (Jilani \& Asim, 2010). The role of FDI is important in the economic growth of any country, and this subject has picked up speed in early 1980s. Over the last two decades, many developing countries like Pakistan have devoted a great attention to encouraging the inflows of FDI to boost the economy (Zaman et al. 2012). The theoretical prospects for FDI inflows suggest that FDI is a combination of capital stocks, technology and technical know-how which expands the market access, provides positive technical spillovers and improve human capital hence promoting the economic growth of a country Blomström, Kokko, \& Zejan (1994) and Zhang (1999). 
The role of foreign direct investment is very important for its recipient countries economic development. Investment in a county whether it is local or foreign depends on different factors and any change or move in direction of these factors result a significant change in investment. Inverters always prefer to invest in a healthy and safe environment. Any unfavorable move in this environment makes the investor too much conscious. According to M. Khan (2012) due to political instability an investor loses its confidence in the host country and thinks many time before making investment as they consider it as risky investment. Therefore in order to increase the FDI inflows in recipient country and to attract foreign investors, there should be stability in exchange rate and politics in host country (Urata \& Kiyota, 2003). Terrorism is another major factor that is significantly reducing the FDI inflows in host country. There are several other macroeconomic variables that are affecting FDI inflows such as money supply, interest rates, exchange rates, inflation, stock market, tariff rates and political and economical instability.

In most of the developing countries, foreign direct investment is largely recognized as growth-enhancing factor (M. A. Khan, 2007). There are many advantages that FDI offers to a host country; it increase the stock of human capital, FDI inflows can be used for current account deficit, ease the access to new technologies, introduces the modern technologies and utilization and exploration of local raw materials (Falki, 2009).

The economy of Pakistan is mainly relying on foreign capital inflows in terms of finance and technology (Siddiqui \& Kemal, 2002). But traditionally Pakistan has not been a large recipient of FDI. Figure 1 shows the net inflows of FDI in Pakistan from 19802013. We can see that FDI inflow starts form 1980 as small inflows and in 1995 the FDI inflow in Pakistan increased followed by decreased trend till 2003. After 2003, the inflow of FDI in Pakistan is increased rapidly till 2007 mid and during this period it reaches the peak inflow. In 2008 the FDI inflow decreases significantly this may happen due to the financial crisis impact, and after 2011 the inflow of FDI is increased again slightly till 2013. There are several reasons for this decreased trend of FDI in Pakistan. Unfortunately, during last two decades the economy of Pakistan suffers a lot from rapidly growing population, political disputes, high inflation rates and its internal conflicts and confrontation with India. Low exports, inadequate investment in socio-economic infrastructure also cause for this decreasing trend. These multifaceted problems of Pakistan's economy have reached at crucial stage in late 1990s. The burden of public sector mismanagement and weak form of governance has been passed in to different sectors in Pakistan. Although Pakistan's economy has made developments in its economic growth variables but unfortunately the consistency of the growth has not been constant.

\section{FDI net inflows in Pakistan (1980-2013)}

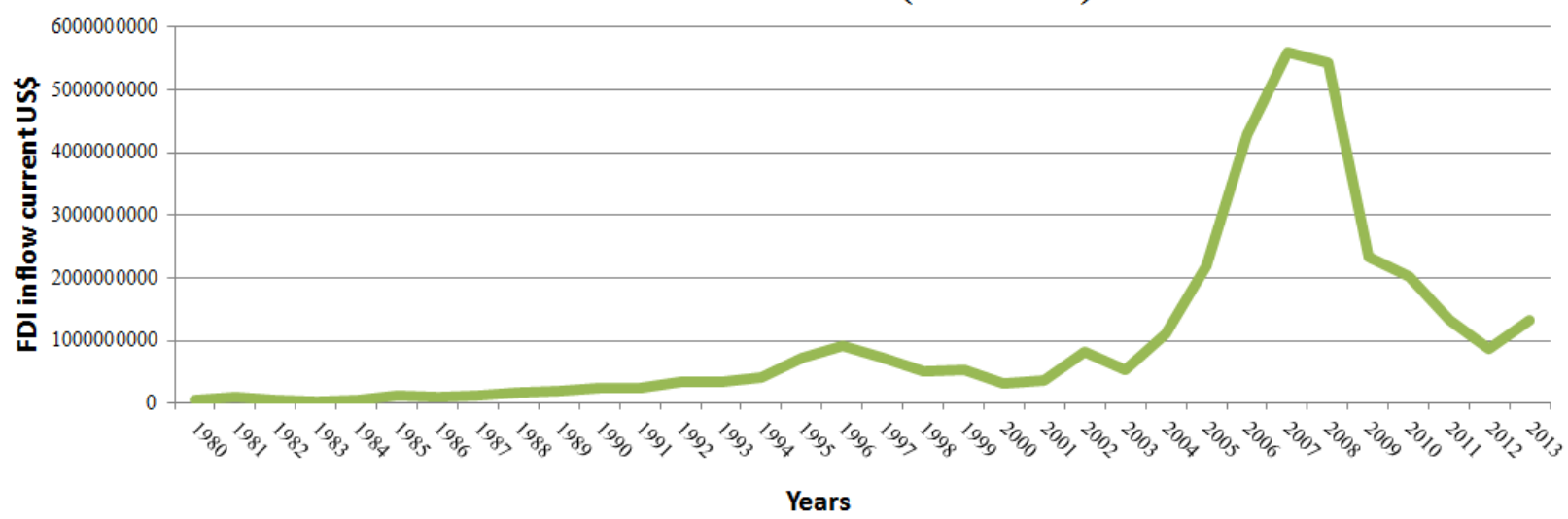

Figure 1.Net inflow of FDI in Pakistan 
This study uses different statistical techniques on the secondary data for the period of 1980 to 2013 and efforts has been made to find out the factors affecting the FDI inflows in Pakistan. This study tries to find out the following research questions:

- What is the impact of terrorism attacks on FDI inflows in Pakistan?

- What is the impact of different macroeconomic variables such as market size, interest rate, inflation rate, Trade openness, democracy on the FDI inflows in Pakistan?

Similarly, the objectives of this study is to empirically investigate the relationship between macroeconomic variables such as terrorism attacks, market size, interest rate, inflation rate, Trade openness, democracy and FDI inflows in Pakistan for the period of 1980 to 2013 through ARDL approach.

The selected sample time period of this study is 1980 to 2013 because several internationalization and liberalization policies were implemented during this period. These policies results in opening up the borders for international trade, the privatization process, lessening control of the financial sector and removing bans on foreign investments in different sectors. Pakistan's economy is suffering for recent wave of political instability and terrorism attacks which significantly reduces the economic growth and FDI in Pakistan (Zaman, Khan, \& Ahmad, 2012). According to Urata \& Kiyota (2003) in order to gain the foreign investors trust and increasing the FDI inflows, there should be stability in politics and exchange rates.

\section{LITERATURE REVIEW}

Literature on FDI inflows and macroeconomic variables highlights mixed findings in different countries. Researchers in past give more emphasis on the determinants of FDI in different economics (e.g., Gastanaga, Nugent, \& Pashamova, 1998; Chakrabarti, 2001; Moosa \& Cardak, 2006). Findings of these researches found different macroeconomic factors that are contributing towards FDI inflows. Nasir \& Hassan (2011) argues that FDI inflow provided many benefits to its host country such as availability of foreign funds, new and innovative technological skills and it also improves the country's economic growth. There is a vast literature which discuss about FDI and shows the relation of FDI with different variables as Onuorah \& Nnenna (2013) tested the short run and long run relationship among macroeconomic variables and FDI in Nigeria. The study period for their research is from 1980 to 2010 . By using Johensen co integration, vector auto regressive and impulse response function, they found GDP as negatively influencing the FDI while all other variables have positive impact on FDI.

Aqeel, Nishat, \& Bilquees (2004) examined the impact of different policy variables and labor cost on FDI in Pakistan for the period of 1961-2002. The study uses co integration and error correction models to find out the relationship among macroeconomic variables and FDI in Pakistan. The results show that market size is positively related with FDI while labor cost and tariff rates have negative impact on FDI in Pakistan. Furthermore they suggest that policy variables plays important role in attracting FDI inflows in Pakistan.

Zaman et al. (2012) modeled a study in Pakistan for the period of 1980 to 2008 by taking macroeconomic variables like political index, exchange rates, GDP growth rate and energy imports. They tested the impact of these variables on FDI before and after liberalization period. Results show that among most of the variables, political instability plays important significant contribution towards FDI in Pakistan. They suggest that political stability is an important factor to attract the foreign investor. Similarly Mahmood et al. (2012) also conducted a study in Pakistan for the period of 1970 to 2007. They suggest that economic freedom and democracy are the factors that have positive impact on countries national savings. 
Subhani, Lakhiya, \& Osman (2011) analysis the democratic and non-democratic GOVT of Pakistan and suggest that non-democratic GOVT improves the country's economic condition. Furthermore, they argue that good governance is necessary for the financial betterment of the country whether it comes from democratic of non-democratic GOVT. Similarly Nasir \& Hassan (2011) estimate a study in South Asia to test the impact of macroeconomic variables and economic freedom on FDI. The results show that market size and economic freedom is positively related with FDI in South Asia, whereas volatility in exchange rate reduces the FDI in host country. Another study is conducted by M. A. Khan \& Khan (2011) in Pakistan for the period of 1981 to 2008 for testing the long run and short run relationship between FDI and GDP growth rate of Pakistan. By using co integration and Granger Causality test they find that in short run both variables move together and cause each other while in long run, there is a unidirectional causality running from GDP to FDI.

Shahzad \& Zahid (2012) estimated regression model for determining the determinants of FDI in Pakistan for the period of 1991 to 2010. The results provide evidence that trend of domestic investments, market size and inflation rate have positive impact on FDI inflows in Pakistan while tax rates and interest rate are insignificant factors for FDI in Pakistan. Awan et al. (2010) finds the factors affecting the FDI in Pakistan. The sample selection is from 1971 to 2008. Using ECM their results show that debt service, inflation, trade openness and gross capital formation has positive impact on FDI in Pakistan.

The ever growing literature on foreign direct investment show that different studies have been conducted in Pakistan with respect to FDI and different macroeconomic variables in different time spans. However this study uses some unique variables and methodology as never done before such as terrorism attacks, inflation rates, interest rates, trade openness, market size and governance. The unique statistical approach is used in this study is ARDL approach to find out the long run and short run relationships among these variables and FDI in Pakistan for the period of 1980-2013.

\section{Conceptual Framework}

After reviewing the literature, the proposed conceptual framework for this study is given in figure 2. Foreign direct investment (FDI) is the dependent variable while terrorism attacks, inflation rate, market size, governance, trade openness and inflation rate are the independent variables.

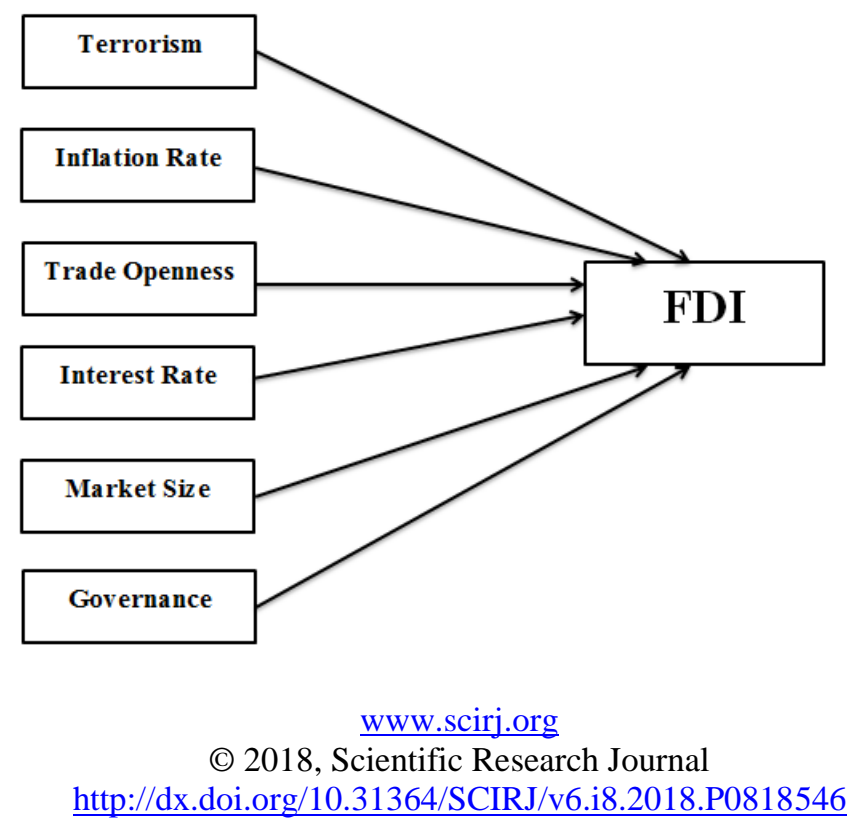




\section{Figure 2.Conceptual framework}

\section{Hypotheses of the Study}

This study is based on the following hypothesis based on the previous studies.

H 1: Terrorism attacks has negative impacts on foreign direct investment in Pakistan for the period of 1980-2013

H 2: Inflation rate has significant impact on foreign direct investment in Pakistan for the period of 1980-2013

H 3: Interest rates has significant impact on foreign direct investment in Pakistan for the period of 1980-2013

H 4: Trade openness has positive significant impact on foreign direct investment in Pakistan for the period of 1980-2013

H 5: Market size has positive significant impact on foreign direct investment in Pakistan for the period of $1980-2013$

H 6: Governance has significant positive impact on foreign direct investment in Pakistan for the period of 1980-2013

\section{RESEARCH METHODOLOGY}

This study uses secondary data for analysis purpose. The targeted population is Pakistan and the sample consists of annual data taken from different databases for the period of 1980-2013. The data for FDI, market size, inflation rate, interest rate and trade openness is collected from World Bank Database and terrorism data is collected from Global Terrorism Database. This study adopts various methods of statistical data analysis to achieve its goals. Data analysis is conducted using Eviews for ARDL approach and other diagnostics tests (M. Khan, 2012; Aqeel et al., 2004; Urata \& Kiyota, 2003; Nasir \& Hassan, 2011; Hakro \& Ghumro, 2007; Shamsuddin, 1994); Hara \& Razafimahefa, 2005). The statistical techniques used in this study are:

1. Descriptive statistics

2. Correlation matrix

3. Unit root test

4. Akaike information criteria

5. Autoregressive distributive lag bound test

6. ARDL co integrating and long run form

In order to check the accuracy of results, the assumptions of ARDL model ${ }^{1}$ are tested and satisfied.

The operational model for this study is:

$$
F D I=\beta 0+\beta 1(T E)+\beta 2(I R)+\beta 3(C P I)+\beta 4(O P)+\beta 5(M S)+\beta 6(G O V)+\mu
$$

\footnotetext{
${ }^{1}$ Data is free from autocorrelation Residuals are normally distributed Data is free from heteroscedesticity
} 
In this model FDI is the foreign direct investment and is our dependent variable, whereas all variables of the right hand side of the equation are independent variables. TE is the all incidents of terrorism, IR is the money market interest rate, CPI is the consumer price index and is used as inflation rate, OP is the trade openness is measured as exports BOP + imports BOP, MS is the market size is measured as gross domestic product (GDP) in Pak rupees and GOV is the dummy variable for governance and is equal to 1 for democratic regimes (1988-98) and (2007-2013) and otherwise 0.

\section{RESULTS AND DISCUSSIONS}

\section{Descriptive statistics}

Summary of statistics of all variables is presented in table 1. The results of descriptive statistics show that an average FDI inflow in Pakistan is 0.1965 with standard deviation of 0.5275. It can be observed from the table 1.1 variables FDI, CPI, Market Size and terrorism are positively skewed, while the variables interest rate, trade openness and governance are negatively skewed variables. Kurtosis values of FDI, interest rate, trade openness and governance is less than three representing leptokurtic distribution and other variables like CPI, Market Size and Terrorism has kurtosis values greater than three which means meso-kurtic distribution. P-value of Jarque-Bera test is greater than 0.01 which shows that data is normally distributed.

Table 1.Descriptive statistics

\begin{tabular}{ccccccc}
\hline Variables & Mean & Std. Dev. & Skewness & Kurtosis & Jarque-Bera & Probability \\
\hline FDI & 0.196578 & 0.527511 & 0.555119 & 2.366288 & 2.247052 & 0.325131 \\
CPI & 9.852094 & 5.201201 & 1.153059 & 3.983559 & 8.371034 & 0.015214 \\
MS & 572.3378 & 279.3757 & 1.248615 & 3.258091 & 8.642663 & 0.013282 \\
IR & 9.454545 & 1.872347 & -0.246931 & 2.106653 & 8.666305 & 0.013126 \\
OP & 0.342913 & 0.025454 & -0.218511 & 2.775773 & 1.432709 & 0.48853 \\
TE & 672.6667 & 1138.335 & 2.254764 & 7.602949 & 0.331741 & 0.847156 \\
GOV & 0.757576 & 0.435194 & -1.202082 & 2.445000 & 7.094011 & 0.010607 \\
\hline
\end{tabular}

\section{Correlation matrix}

Table 2 shows the results of correlation matrix of all variables of this study. Results shows that governance and trade openness is positively correlated with FDI in Pakistan and on the other hand inflation, market size, interest rates and terrorism attacks is negatively correlated with FDI. The correlation of governance with all other variables shows that only inflation is negatively correlated with FDI while all other variables are positively correlated with FDI. Similarly market size and terrorism are highly correlated with each other.

\section{Table 2.Correlation matrix}




\begin{tabular}{cccccccc}
\hline & FDI & GOV & CPI & MS & IR & OP & TE \\
\hline FDI & 1 & - & - & - & - & - & - \\
GOV & 0.132230 & 1 & - & - & - & - & - \\
CPI & -0.246357 & -0.042837 & 1 & - & - & - & - \\
MS & -0.211501 & 0.350628 & 0.380082 & 1 & - & - & - \\
IR & -0.132822 & 0.101108 & 0.382144 & 0.586679 & 1 & - & - \\
OP & 0.048612 & 0.318484 & -0.120468 & -0.255754 & -0.114898 & 1 & - \\
TE & -0.317771 & 0.311451 & 0.304026 & 0.860009 & 0.461619 & -0.12884 & 1 \\
\hline
\end{tabular}

\section{Unit root test}

This study uses $\mathrm{N}$-j Peron test to check the stationary of the variables in data set. The reason to use this test is that ADF test is not appropriate if numbers of observations are less. If number of observations are less than N-j Peron test is used. The results of Unit Root test are described in table 3. It shows that all the variable series is stationary, but stationery level is different for different variables. Some variables are significant at level and some are significant at first difference. Independent variables Market Size, Terrorism and Governance are significant at First difference while the variables FDI, Interest rate, CPI and trade openness are stationery at level. So $\mathrm{HO}$ is rejected because computed values for each variable is less than critical values, and concluded that series is stationery.

\section{Table 3.Unit root test results}

\begin{tabular}{cccccc}
\hline Variables & Critical value & Computed value & Significant or not & Results & At level or first difference \\
\hline FDI & -13.8 & -15.4055 & Significant & Stationary & Level \\
MS & -13.8 & -14.8254 & Significant & Stationary & First Difference \\
IR & -8.1 & -8.47902 & Significant & Stationary & Level \\
CPI & -13.8 & -15.9884 & Significant & Stationary & Level \\
OP & -8.1 & -10.0106 & Significant & Stationary & Level \\
TE & -13.8 & -15.2791 & Significant & Stationary & At first difference \\
GOV & -13.8 & -15.4968 & Significant & Stationary & At first difference \\
\hline
\end{tabular}

\section{Akaike information criteria}

To select the optimal lag selection of variables Akaike information criteria is used and the results are shown in figure 3. Akaieke information criteria provide the optimal number of lags for individual variables. Graph 4.1 provides top twenty models with different lag numbers. The acceptance criterion for Akaike Information is to select the model having minimum Akaike Value. In this study series of lag $(2,1,3,3,3,3,3)$ will be used due to minimum Akaike value of 0.13 Approximately. 


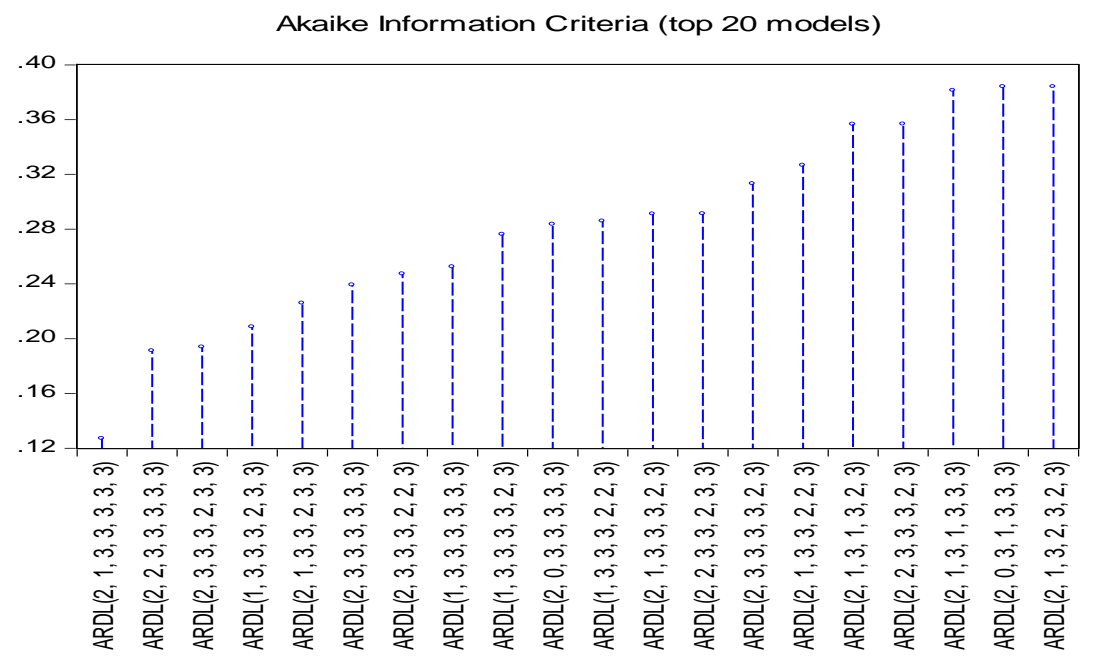

Figure 3.Akaike information criteria results

\section{Autoregressive distributed lag bound test}

On the basis of unit root results Autoregressive distributed lag distributive (ARDL) approach is applied because all of the variables are not significant at level. If stationery level of variables different then ARDL approach is applied to test the relationship among variables. First we apply ARDL model and then apply bound test to know about the long run relationship. Table 4 shows the results of ARDL bound test. It reports F- statistic and critical values by (Pesaran, Shin, \& Smith, 2001). The calculated value of F-statistic is 13.48031 which is more than the critical value of lower and upper bounds even at $1 \%$ level of significance. The estimation results provide the evidence that there is a long run relationship exists between FDI and microeconomic variables.

Table 4.ARDL bound test

\begin{tabular}{ccc}
\hline F-statistic & \multicolumn{2}{c}{13.48031} \\
\hline \multicolumn{3}{c}{ Critical Value Bounds } \\
\hline Significance & I0 Bounds(Lower bounds) & I1 Bound(Upper bounds) \\
\hline & & \\
$10 \%$ & 2.12 & 3.23 \\
$5 \%$ & 2.45 & 3.61 \\
$2.50 \%$ & 2.75 & 3.99 \\
$1 \%$ & 3.15 & 4.43 \\
\hline
\end{tabular}

\section{ARDL co integrating and long run form}

Table 5 shows the results of ARDL co integrating and long run form. It contains two parts, co integrating form and long run coefficients. The co integrating form results describe the short run association between FDI and macroeconomic variables, while long run coefficients show the long run association between dependent and independent variables. In this table the CointEq (-1) is the cointegrating equation. It must be negative and significant at 5\% and in our results we found it as negative and significant at $1 \%$, it means co integrating equation is highly significant and it shows that $189.6 \%$ of disequilibrium from the previous year shock 
converges back to the long run equilibrium in the current year. The remaining part of this table represents the short run associations among dependent and independent variables. We can see that market size is significant at 5\% and positively relates with the FDI in short run, whereas lag 1 of market size is also significant at 5\% but negatively relates with FDI in short run. Furthermore lag 2 of market size is also significant and again has positive impact on FDI in short run. The CPI lag 1 is significant at $1 \%$ and negatively associated with the FDI inflows in short run in Pakistan. Finally terrorism is significant at $1 \%$ confidence interval level and has positive impact on FDI but lag 1 and lag 2 of terrorism has negative impact on FDI in short run. The other independent variables show no significant impact on FDI in short run.

The long run coefficients show the relationship between dependent and independent variables in long run. The results show that CPI, IR, TE and GOV are significant and positively associated with FDI in long run, whereas MS is negatively associated with FDI in long run. The trade openness has no impact on FDI inflows in long run in Pakistan.

Table 5.ARDL co integrating and long run form

\begin{tabular}{|c|c|c|c|c|}
\hline \multicolumn{5}{|c|}{ Cointegrating form } \\
\hline Variable & Coefficient & Std. Error & t-Statistic & Prob. \\
\hline$\overline{\text { FDI LAG } 1}$ & 0.292892 & 0.186435 & 1.571011 & 0.1770 \\
\hline MS & 0.013385 & 0.003498 & 3.826017 & $0.0123 * *$ \\
\hline MS LAG 1 & -0.014814 & 0.004525 & -3.273516 & $0.0221^{* *}$ \\
\hline MS LAG 2 & 0.075149 & 0.004372 & 17.189899 & $0.0000 * * *$ \\
\hline CPI & 0.042441 & 0.02853 & 1.487579 & 0.1970 \\
\hline CPI LAG 1 & -0.196695 & 0.027651 & -7.11352 & $0.0009 * * *$ \\
\hline CPI LAG 2 & -0.00043 & 0.027506 & -0.015616 & 0.9881 \\
\hline IR & -0.000182 & 0.068935 & -0.002638 & 0.9980 \\
\hline IR LAG 1 & 0.000381 & 0.093415 & 0.004075 & 0.9969 \\
\hline IR LAG 2 & -0.652052 & 0.081166 & -8.033565 & $0.0005^{* * *}$ \\
\hline OP & -0.53771 & 6.359759 & -0.084549 & 0.9359 \\
\hline OP LAG 1 & -0.147131 & 4.004326 & -0.036743 & 0.9721 \\
\hline OP LAG 2 & 1.619239 & 8.951291 & 0.180894 & 0.8636 \\
\hline $\mathrm{TE}$ & 0.527767 & 0.000214 & 2461.389353 & $0.0000 * * *$ \\
\hline TE LAG 1 & -0.527767 & 0.000305 & -1732.89087 & $0.0000^{* * *}$ \\
\hline TE LAG 2 & -0.527767 & 0.000261 & -2024.095047 & $0.0000 * * *$ \\
\hline GOV & 0.527767 & 0.473272 & 1.115145 & 0.3155 \\
\hline Coint $\mathrm{E} q(-1)$ & -1.89632 & 0.326447 & -5.80896 & $0.0021 * * *$ \\
\hline
\end{tabular}




\begin{tabular}{ccccc}
\hline \multicolumn{5}{c}{ Long Run Coefficients } \\
\hline Variable & Coefficient & Std. Error & t-Statistic & Prob. \\
\hline MS & -0.033893 & 0.005908 & -5.736495 & $0.0023^{* * *}$ \\
CPI & 0.177305 & 0.03669 & 4.832552 & $0.0047^{* * *}$ \\
IR & 0.3431 & 0.068919 & 4.978298 & $0.0042^{* * *}$ \\
OP & -1.171337 & 3.976292 & -0.29458 & 0.7802 \\
TE & 1.113245 & 0.191756 & 5.805544 & $0.0021^{* * *}$ \\
GOV & 0.556623 & 0.182994 & 3.041761 & $0.0287 *$ \\
Constant & 0.278311 & 1.523524 & 0.182676 & 0.8622 \\
\hline$* *$ Significant at 1\% & & & & \\
$* *$ Significant at 5\% & & & & \\
$*$ Significant at 10\% & & & &
\end{tabular}

\section{CONCLUSION AND RECOMMENDATIONS}

The aim of this research is to test the impact of different macroeconomic variables on FDI inflows in Pakistan by taking annual data for the period of 1980 to 2013. Macroeconomic variables used in this study are interest rates, inflation rate, democracy, terrorism, and market size and trade openness. The major findings of this study show that inflation rate, interest rates, democratic GOVT regimes and terrorism attacks are affecting the FDI inflows in Pakistan and all has long run association with FDI, whereas in short run inflation, interest rates and terrorism attacks are negatively and market size show positive relationship with FDI inflows in Pakistan. Furthermore, trade openness has no impact on FDI in long as well as short run and is insignificant.

The findings of this study suggest that increased interest rates and inflation rates in Pakistan will cause lower FDI inflows. The gross domestic product as market size increases, it has positive impact on FDI inflows in Pakistan. The terrorisms attacks are major problem for Pakistan's economy. The results show that previous terrorism attacks are affecting FDI inflows negatively in the short time span, but in long run it becomes positive. It means Pakistan economy has capacity to cover its problems and not much suffers from such attacks.

This study has some unique contributions to the literature on FDI and macroeconomic variables. This research provides some useful implications to the GOVT, foreign investors and policy makers of Pakistan because FDI inflow is very essential for its economic growth. The results suggest a positive relationship between market size and FDI inflow; this brings up the attention for the policy makers to establish new industries, so that country industrial production, exports and employment will increase and that will ultimately bring FDI inflows in Pakistan.

The current study has also some limitations, firstly this study analysis the selective macroeconomic variables not covering all factors. Secondly, this study is undertaken by using annual data set of the Pakistan's economy for the period of 1980 to 2013 . Therefore generalizability is another constraint of this study, because Pakistan's economy has different political conditions and law and order situation. Future research can be done by expanding the time span of the current study for 2013 to onward by taking some other important macroeconomic variables and by applying different statistical model for better results. 


\section{REFERENCES}

[1] Aqeel, Anjum, Nishat, Mohammed, \& Bilquees, Faiz. (2004). The Determinants of Foreign Direct Investment in Pakistan [with Comments]. The Pakistan Development Review, 651-664.

[2] Awan, Muhammad Zahid, Uz Zaman, Khair, \& Khan, Bakhtiar. (2010). Determinants of foreign direct investment in services sector of Pakistan: An Econometric Approach. Global Financial Crisis: Causes, Emerging Trends and Strategy, $5(2), 167$.

[3] Blomström, Magnus, Kokko, Ari, \& Zejan, Mario. (1994). Host country competition, labor skills, and technology transfer by multinationals. Review of World Economics, 130(3), 521-533.

[4] Chakrabarti, Avik. (2001). The determinants of foreign direct investments: Sensitivity analyses of cross-country regressions. kyklos, 54(1), 89-114.

[5] Falki, Nuzhat. (2009). Impact of foreign direct investment on economic growth in Pakistan. International Review of Business Research Papers, 5(5), 110-120.

[6] Gastanaga, Victor M, Nugent, Jeffrey B, \& Pashamova, Bistra. (1998). Host country reforms and FDI inflows: How much difference do they make? World development, 26(7), 1299-1314.

[7] Hakro, Ahmed Nawaz, \& Ghumro, Akhtiar Ahmed. (2007). FOREIGN DIRECT INVESTMENT, DETERMINANTS AND POLICY ANALYSIS: CASE STUDY OF PAKISTAN: Glasgow University, Glasgow, and Shah Abdul Latif University, Khaipur.

[8] Hara, Masayuki, \& Razafimahefa, Ivohasina F. (2005). The determinants of foreign direct investments into Japan. Kobe University economic review, 51, 21.

[9] Jilani, Sidrat, \& Asim, Muhammad. (2010). Exploring Impact of Macro Economic Variables on GDP of Pakistan. Journal of Management and Social Sciences, 6(2), 65-73.

[10] Khan, Muhammad Arshad. (2007). Foreign direct investment and economic growth: the role of domestic financial sector: Pakistan Institute of Development Economics.

[11] Khan, Muhammad Arshad, \& Khan, Shujaat Ali. (2011). Foreign direct investment and economic growth in Pakistan: A sectoral analysis. Pakistan Institute of Development Economics, PIDE Working Paper(67).

[12] Khan, Mushtaq. (2012). Governance and growth: history, ideology and methods of proof. Good growth and governance in Africa: rethinking development strategies, 51-79.

[13] Mahmood, Khalid, Chaudhry, Imran Sharif, \& Mahmood, Khalid. (2012). National Savings, Investment and Institutional Freedoms in Pakistan. International Journal of Asian Social Science, 2(6), 782-789.

[14] Moosa, Imad A, \& Cardak, Buly A. (2006). The determinants of foreign direct investment: An extreme bounds analysis. Journal of Multinational Financial Management, 16(2), 199-211.

[15] Nasir, Zafar Mueen, \& Hassan, Arshad. (2011). Economic freedom, exchange rates stability and FDI in South Asia. The Pakistan Development Review, 423-432.

[16] Noorbakhsh, Farhad, Paloni, Alberto, \& Youssef, Ali. (2001). Human capital and FDI inflows to developing countries: New empirical evidence. World development, 29(9), 1593-1610.

[17] Onuorah, Anastasia Chi-Chi, \& Nnenna, Okoli Margaret. (2013). Long run relationship between macroeconomic variables and FDI in Nigeria. Developing Country Studies, 3(1), 162-169.

[18] Pesaran, M Hashem, Shin, Yongcheol, \& Smith, Richard J. (2001). Bounds testing approaches to the analysis of level relationships. Journal of applied econometrics, 16(3), 289-326.

[19] Shahzad, Naveed, \& Zahid, Muhammad. (2012). The Determinants of Foreign Direct Investment in Pakistan. Abasyn University Journal of Social Sciences, 4(2). 
[20] Shamsuddin, Abul FM. (1994). Economic determinants of foreign direct investment in less developed countries. The Pakistan Development Review, 41-51.

[21] Siddiqui, Rizwana, \& Kemal, AR. (2002). Poverty Reducing or Poverty Inducing. A CGE Based Analysis of Foreign Capital Inflows in Pakistan. Department for International Development (DFID) UK.

[22] Subhani, Muhammad Imtiaz, Lakhiya, Zubair, \& Osman, Amber. (2011). The Structure and Performance of Economy of Pakistan (Comparative Study between Democratic and Non-Democratic Governments). International Journal of Business and Social Science, 2(14).

[23] Urata, Shujiro, \& Kiyota, Kozo. (2003). The impacts of an East Asia FTA on foreign trade in East Asia: National Bureau of Economic Research.

[24] Zaman, Khalid, Khan, Muhammad Mushtaq, \& Ahmad, Mehboob. (2012). RETRACTED: The relationship between foreign direct investment and pro-poor growth policies in Pakistan: The new interface. Economic Modelling, 29(4), 1220-1227.

[25] Zaman, Khalid, Shah, Iqtidar Ali, Mushtaq Khan, Muhammad, \& Ahmad, Mehboob. (2012). Macroeconomic factors determining FDI impact on Pakistan's growth. South Asian Journal of Global Business Research, 1(1), 79-95.

[26] Zhang, Kevin H. (1999). How does FDI interact with economic growth in a large developing country? The case of China. Economic Systems, 23(4), 291-304. 